\title{
O xamanismo ameríndio como tecnologia de relações
}

\author{
Amerindian shamanism as a technology of relations
}

Wil Wandreus da Silva Correia ${ }^{1}$

Resumo: Este artigo tem o objetivo de fazer apontamentos acerca da natureza do xamanismo ameríndio; seus processos de criação; e como se torna o elemento cardinal das sociedades indígenas. Nessa abordagem serão articulados, principalmente, Mircea Eliade (1972; 1998), Lévi-Strauss (1955; 1975; 2008) e Viveiros de Castro (2006; 2007; 2009; 2014), como referencial etnográfico e teórico antropológico, de uma base estratégica que permita uma perspectiva atualizada para as Ciências das Religiões; ultrapassando, então, a análise da esfera ritualística, para se estender a um modo de vida intraespecífico.

Palavras chaves: xamanismo transversal,cosmologia ameríndia, espiritualidade indígena,perspectivismo

Abstract: This article aims to analyse the nature of Amerindian shamanism; their creation processes; and how it becomes the cardinal element of indigenous societies. In this approach, Mircea Eliade, (1972; 1998), Lévi-Strauss (1975; 2008) e Viveiros de Castro (2007; 2009; 2014), will be articulated. An ethnographic and anthropological theoretical framework, with a strategic basis will be also made. It allows an updated perspective for the Sciences of Religions beyond the analysis of the ritualistic sphere, in order to extend it to an intraspecific way of life.

Key words: transversal shamanism, amerindianscosmology,indigenous spirituality, perspectivism

\section{Introdução}

Esse artigo tem a pretensão de diagramar os principais elementos que podem ser encontrados em um xamanismo ameríndio. Quando é apontado um xamanismo ameríndio como tecnologia de relações, faz-se necessário averiguar quais ferramentas compõe essa tecnologia, e com o que se relaciona esse xamanismo. Por isso mesmo, é preciso percorrer sobre as atividades que constituem essa prática, em cada uma de suas funções, entendendo a dimensão dos seus processos.

Antes, porém, talvez seja importante pontuar a escolha dos autores cardinais dessa abordagem. Mircea Eliade é elencado aqui, não só por ser precursor em etnologias sobre os xamanismos; mas por ser passagem obrigatória na formação em Ciências das Religiões; e dentro de sua obra usada aqui, foram priorizados exemplos

\footnotetext{
${ }^{1}$ Jornalista pela Unicarioca - RJ; cursou licenciatura em Ciências das Religiões na Unimontes - MG; mestrando em Ciências das Religiões pela Universidade Federal da Paraíba - UFPB. E-mail: wildoreino@gmail.com.
} 


\section{SACRILEGENS

de povos ameríndios como os Cuna e Osage (ELIADE, 1972, pp.15,28); isso para se alinhar a proposta de Lévi-Strauss, entidade elevada da antropologia feita nas terras ameríndias, que através da sua série chamada "Mitológicas" foi responsável intelectual por Viveiros de Castro ter “descoberto os índios” (VIVEIROS DE CASTRO, 2007, p.58) na antropologia que pratica. E as elaborações desse último, servirá de lente principal aqui.

É em Viveiros de Castro que vemos que as Américas indígenas compartilham um fundo conectivo comum, que influencia nas relações sociais dos viventes; na compreensão do lugar de manifestação de afeto; e os duplos caminhos de olhares sobre o mesmo e o múltiplo. Isso dentro da abordagem chamada de "perspectivismo ameríndio" e "multinaturalismo”2 (VIVEIROS DE CASTRO, 2009). Essa intuição préconceitual da realidade, a pressuposição de uma atenuante virtual que conecta a existência, também se convencionou a ser chamada de "espírito" (VIVEIROS DE CASTRO, 2007, p.33), que nesses termos é a imaterialidade da imanência.

Viveiros de Castro aponta uma cosmologia indígena habitada por espíritos, animais, xamãs, mortos, brancos, mitos, sonhos, alucinógenos, festas, caça e a floresta, onde convivem uma humanidade arcaica e uma vitalidade atual (VIVEIROS DE CASTRO, 2006, p.321); ele faz uso dos conceitos da filosofia da diferença ${ }^{3}$, para dar conta de suas observações, por exemplo, como da narrativa do xamã yanomami Davi Kopenawa, sobre "humanidade molecular de fundo, ocultada por formas molares não-humanas, e dos múltiplos afetos não-humanos" (Idem), intermediados pelos xamãs. Aliás, nesse processo, a atividade do xamã, conforme descrita adiante, é vital para essa atualização; uma vez que no artigo referenciado, sua profundidade é condensada em colocações como sendo "um ser múltiplo, uma micropopulação de agências xamânicas abrigada em um corpo" (Ibidem, p.322), uma "federação de agentes sobrenaturais”, que precisa ser mais esmiuçado em suas funções e existência.

Conhecer, como é proposto neste artigo, os elementos principais para prática xamânica, é importante para entender o que essa relação constrói a partir do pano de fundo espiritual: o plano de imanência. Essa relação só é construída a partir da "consciência”, compreensão, ou assentimento, da consideração de todas as

\footnotetext{
2 Conceitos desenvolvidos por Viveiros de Castro em Metafísicas Canibais (2009). O perspectivismo ameríndio compreenderia a consideração do ponto de vista dos existentes. O multinaturalismo a diversidade na natureza em semelha de cultura.

3 Em A inconstância da alma selvagem (2014), Viveiros de Castro já dialoga com a filosofia de Guilles Deleuze. Mas, é em Metafísicas Canibais (2009) que deixa explicita a sua intenção de atravessar todo o texto com as teorias de Deleuze \& Guattari.
} 
considerações. Ou seja, os entes são pontos de vista; e a multiplicidade só é possível por conta das diferentes perspectivas em trânsito. Nesse ambiente, sem "hierarquias fixas de ponto de vista entre os seres", ou ainda, a falta de "igualdade de estatuto entre os humanos e os extra-humanos"; a conexão é feita pelo xamanismo (VIVEIROS DE CASTRO, 2009, p. 179), que transforma o pano de fundo perspectivista em prática da imanência.

O solo do plano de imanência xamânico, na proposição de Viveiros de Castro, seria uma "experiência do pensamento"; mas, não na imaginação de uma experiência; não se trata disso; porém, sua travessia pela "entrada no pensamento pela experiência real"; como as de "gerações de etnógrafos da Amazônia indígena" e suas elaborações antropológicas. Tais elaborações consideram as "ideias indígenas como conceitos", e delas extraem as determinações dos personagens envolvidos e a "matéria do real que eles põem" (VIVEIROS DE CASTRO, 2009, p.217). Uma tecnologia das relações xamânicas, extração para uma antropologia do conhecimento como "uma transformação da práxis indígena"; dessa forma conferir que "o outro dos outros é também Outro". E em uma conclusão geral, traçar um "plano de imanência comum a seu objeto" (Idem, p.260). A partir de toda essa construção, uma "imanência real entre existência e experiência na constituição de um multiverso relacional" (DANOWSKI \& VIVEIROS DE CASTRO, 2015, p. 103), considerando, então, a consubstancialidade entre humanidade e mundo.

A ideia de um "multiverso relacional" constituído pela "existência e experiência" na construção necessária do plano de imanência, ganha sua valência profícua no texto escrito a quatro mãos por Déborah Danowski e Viveiros de Castro, o "Há mundo por vir? Ensaio sobre os medos e os fins" (2015). Os autores trafegam pelos mitos indígenas de "fim de mundo" para pensar as possibilidades de um mundo de todos. Incluir a extensão do "plano" para além das fronteiras indígenas dá o tom de urgência dos procedimentos dos resultados antropológicos ditos acima: "Esse mundo que procede ontologicamente dos humanos (i.e. dos índios) inclui, esclareçamos, os Brancos e sua civilização material" (DANOWSKI \& VIVEIROS DE CASTRO, 2015, p. 103). Um plano de imanência xamânico, nesses termos, precisa incluir, pois não ignora, a existências dos não indígenas, visto que a invasão ocidental nas Américas "deu e continua a dar, margem a uma intensa perplexidade metafísica por parte dos indígenas" (Idem). Um "plano prático-especulativo", dirá os autores; 


\section{SACRILEGENS

que dê conta dos desdobramentos históricos, insurreição automista e o profetismo sobre uma renovação cósmica.

\section{O xamanismo ameríndio}

A base principal na cultura de povos originários é conhecer a origem das coisas, os segredos dessas origens, como elas tornaram a existência, pois isso permite que se saiba onde encontrá-las e como fazer que elas reapareçam (ELIADE, 1972, p.14). Se as narrativas da criação das coisas mostram a relação do espírito que as criou, é possível "assegurar a multiplicação de tal animal ou tal planta” (ELIADE, 1972, p.15), ou seja, reestabelecer a relação com esse espírito de criação.

Quanto mais profundo o conhecimento da natureza das coisas, melhor a relação com elas. Eliade faz o registro a respeito do povo ameríndio Cuna, que leva isso a cabo, quando se tratava de várias ações diárias necessárias, como a origem dos animais para uma boa caça; do ferro, para saber manipulá-lo; do fogo para sua utilização; desde as mais triviais, até não ser ferido letalmente por esses elementos (ELIADE, 1972, p.15). Ou seja, as "coisas" não são meros objetos, são estados de conhecimento para relação.

Há povos ameríndios na densa floresta amazônica que postulam que os espíritos estão entranhados em toda movimentação feita nesse ambiente. Isso logicamente não os exclui, pelo contrário, o ente indígena como parte constitutiva desse cosmo, está em trânsito constante com o fluxo aberto dessa "espiritualização potencial a que todos os seres estão submetidos” (VIVEIROS DE CASTRO, 2014, p.50) que se distribui em atuações distintas.

A categorização espiritual vai seguir a experiência específica de cada povo. Suas nomenclaturas e atividades. Sabe-se que há seres "duplos transcendentes de espécies animais e classes de objetos acessíveis à experiência ordinária” (Idem), ou seja, de relação imediata. E ainda, há os de "manifestação antropomórfica de fenômenos naturais como o trovão, raio, e espíritos com uma forma singular” (Ibidem); esses terão nomes próprios, com correspondências estabelecidas.

$\mathrm{Na}$ espiritualidade potencial manifesta que "a grande divisão mítica mostra menos a cultura se distinguindo da natureza que a natureza se afastando da cultura" (VIVEIROS DE CASTRO, 2014, p. 245), a grande bifurcação de mão dupla entre seres: animais, humanos e espíritos num denso habitat propício. Um cenário de 
sínteses aberrantes, normais e gerais, onde sua integração não está limitada a absorção imediata, mas distribuída em um conjunto de hipóteses elementares com valor instrumental inegável que possibilita a análise teórica que falou Lévi-Strauss (2008); assim, fornecendo a tradução socialmente autorizada de fenômenos cuja natureza profunda tornar-se-ia novamente impenetrável (Idem, p. 200), na tentativa de uma linguagem comunicável.

O intricado de elementos vívidos só é possível de ser sentido, inferido e transmitido através dos xamãs, ou seja, esses personagens que povoam as mitologias, narrativas de criação e origens das coisas (VIVEIROS DE CASTRO, 2014, p. 254). O agregado de mundos cósmicos necessita de uma arte diplomática de atravessamentos no intercâmbio de perspectivas (Idem, p. 246), e não há outra forma de proceder tal política, a não ser através do xamanismo.

Um choque existencial pode ser esse intercambio de perspectivas, se tentarmos entender pela "tradição perpetuamente oscilante entre o monismo naturalista e o dualismo ontológico natureza/cultura” (Ibidem, p. 250) que vai insistir na noção limitante de Natureza; pois se adicionamos mais um elemento espiritual, a Cultura, como avatar comportamental, ao contexto de compreensão, ultrapassará a vaga noção, chegando a, no mínimo, considerar a Sobrenatureza como referencial mais aproximado. Por Sobrenatureza, consideremos aqui as camadas de estrutura que ultrapassam a materialidade dos entes.

A natureza dos existentes, então, possui um espírito; em dimensões escalonadas em conformidade de atuação. A esses entes fractais estarão atribuídos pontos de vista, o que o coloca na posição de sujeito (VIVEIROS DE CASTRO, 2014, p. 254). A insistência em um sistema relacional se deve a essa dupla observação dos seres. Olhares, dentro de perspectivas próprias, que interagem em um universo de personificação, considerações que ultrapassam na noção simples do que é Natureza.

Estamos falando de entidades com relacionalidade: os sujeitos são ou tem espíritos, tendo como propriedade as representações (VIVEIROS DE CASTRO, 2014, p. 259); cultura é natureza do sujeito, e a humanidade como forma geral desse sujeito (Idem, p.255); no conjunto de modos do ser que constitui um habitus, será denominado o corpo como feixe de afecções e capacidades, e que é a origem das perspectivas (Ibidem, p. 255) espirituais. Viveiros de Castro explicita a diferença ocidental nesse imbricamento: 
Dito de outro modo, nossa cosmologia imagina uma continuidade física e uma descontinuidade metafísica entre os humanos e os animais, a primeira fazendo do homem objeto das ciências da natureza, a segunda, das ciências da cultura. O espírito é nosso grande diferenciador: é o que sobrepõe os humanos aos animais e à matéria em geral, o que singulariza cada humano individual diante de seus semelhantes, o que distingue as culturas ou períodos históricos enquanto consciências coletivas ou espíritos de época. $\mathrm{O}$ corpo, ao contrário, é o grande integrador, o veículo da "participação moderna": ele nos conecta ao resto dos viventes, unidos todos por um substrato universal (o ADN, a química do carbono etc.) que, por sua vez, remete à natureza última de todos os "corpos" materiais. (VIVEIROS DE CASTRO, 2014, p. 260).

O cosmo ameríndio será perpassado pelo princípio espiritual de ligação dos entes. Mesmo que seja diferenciado em sua forma, como "força vital” ou "duplo", como observou Lévi-Strauss (2008) na variação do tipo de ser ou objeto. A continuidade não será feita pelo corpo, o modo de manifestação das afecções, mas pelo espírito que é a substância reflexiva de continuidade metafísica (VIVEIROS DE CASTRO, 2014, p. 250) na realização do sensível.

A estrutura em movimento permanece como narrativa mítica de recriação constante. Há uma extensão incontável ameríndia que valida as interpretações e trocas que se produzem constantemente (LÉVI-STRAUSS, 2008, p. 219). Os feixes das relações dos mitos, as unidades constitutivas, as combinações desses feixes, a produção de um sistema atemporal (Idem, p. 227) que nos leva a prática teórica indígena, da "instituição instauradora da mitologia do continente, a saber, aquela que postula a preexistência absoluta de um meio literalmente pré-histórico" (VIVEIROS DE CASTRO, 2009, p. 55) que é expressa pelos existentes em sua interpretabilidade coacessada do "passado que nunca foi presente e que, portanto nunca passou" (Idem), mas que insiste em povoar o presente.

O pano de fundo virtual de espíritos, corpos, mitos, relações múltiplas, perspectivismo, revela a "consciência por manifestações afetivas, cuja natureza profunda e intelectual”, precisa estar em frequência horizontal constante pelo xamanismo como "profetismo de baixa intensidade" (Ibidem). Pois, o intrincamento excedente de significações necessitará sempre de muitos elementos associativos; onde somente "a história da função simbólica permitirá dar conta dessa condição espiritual do homem” (LÉVIS-STRAUSS, 2008, p. 199), nesse caso, na perene recriação do cosmos.

Até aqui, encontramos singularidades difusas que atuam como elementos agenciadores de formação de pensamento como discorremos anteriormente. Ou seja, um misto de corpos que produzem afetos, que por sua vez produzem impressões, que 


\section{SACRILEGENS

geram relações para uma inconsciente que concebe a multiplicidade, que torna um modo de vida de pensamento instituído por espírito, cultura, manifestações, e recriações circulantes. Tudo isso, em uma composição de gradientes que veremos em seguida.

\section{O xamã}

"A mitologia ameríndia, enfim, é uma multiplicidade aberta" (VIVEIROS DE CASTRO, 2009, p. 243), nesse sentido, o xamanismo ameríndio se torna um elemento factral e rizomático, ou seja, com a estrutura múltipla própria da relação de feixes; e com a distribuição e acoplamento necessário de um devir. Por essa razão, embora a inferência de Mircea Eliade seja obrigatória, ela é pouco abrangente, se entendida apenas na afirmação que o xamanismo é uma técnica de êxtase (ELIADE, 1998, p. 16).

O cosmo ameríndio é o espaço múltiplo com habitações de viventes de diversas dimensões da natureza. O xamã, o diplomata, aquele que transita, interage e interpreta esse mundo, é, então, o ser que ultrapassa averiguações inconsciente, conscientes e projeções perspectivas. É por esse meandro que a análise eliadiana adentra na colocação de que o xamã é para além do mago, feiticeiro, curandeiro, pajé ou extático (ELIADE, 1998, p. 15); ultrapassando as várias técnicas de cura, domínios de elementos da natureza, técnicas inesgotáveis de êxtase, e, em sua especialidade, o transe que permite ascensões celestiais e sombrias de sua alma (Idem, p. 17). A noção será sempre extremamente complexa e imprecisa. Talvez um xamã pudesse estar diluído nessa compreensão de Viveiros de Castro:

\footnotetext{
Aqui caberia apenas acrescentar que se essa ordem intensiva não conhece distinção de pessoas nem de sexo, tampouco conhece qualquer distinção de espécies, particularmente uma distinção global entre humanos e nãohumanos: no mito, todos os actantes ocupam um campo interacional único, ao mesmo tempo ontologicamente heterogêneo e sociologicamente contínuo (ali onde toda coisa é "humana", o humano é toda uma outra "coisa"). (VIVEIROS DE CASTRO, 2009, p. 145).
}

O campo interacional e contínuo de natureza ontológica e social é uma consideração necessária para existência do xamã. O xamanismo considera a existência de regiões extraterrenas onde a simultaneidade daquilo que concerne à vida acontece; uma geografia mística que o xamã conhece seus itinerários (ELIADE, 


\section{SACRILEGENS

1998, p. 208). As técnicas xamânicas, então, consistem por excelência no tráfego dessa região cósmica. (Idem, p. 287), seja para condução objetiva das almas, conhecimento cosmológico ou produção do simbolismo capaz de comunicar essas zonas.

Viveiros de Castro reposiciona de certa forma a análise de Eliade, quando as camadas do processo xamânico, onde ambos criam uma espécie de holografia teórica para dar conta das camadas envolvidas. O xamanismo ameríndio, como atividade específica, é a habilidade de certos indivíduos em cruzar barreiras corporais, adotar subjetividades e perspectivas de diferentes existentes (VIVEIROS DE CASTRO, 2009, p. 49), e dessa forma promover as relações necessárias entre os diferentes.

O trânsito constante em diferentes esferas do cosmo se faz necessário para amenizar o conflito de comunicação, buscando a harmonia interespecífica da condição do ambiente (VIVEIROS DE CASTRO, 2009, p. 171). A constância é necessária para se estabelecer o elemento primordial da condição xamânica que é conhecer para agir. Diferente do pensamento moderno ocidental, onde conhecer é eliminar cada vez mais as subjetivações, desumanizar ao máximo até tornar objeto, o xamanismo ameríndio implica o conhecer baseado em personificação, tomar o ponto de vista daquilo que se conhece (Idem, p. 49), dessa forma, perceber os modos e afetos por detrás dos acontecimentos.

Viveiros de Castro vai pensar em um tipo de categorização da atuação do xamã: horizontal, vertical e transversal (VIVEIROS DE CASTRO, 2009, p. 175-180). O xamanismo horizontal diz respeito à relação exterior com os socius, tratando da condição própria da imanência. O vertical compreende ao mestre de cantos, segredos espirituais, cerimônias como nascimento, iniciação, nominação e funerais (Idem). O transversal evoca a relação de pontos de vista perspectivos dos seres em sua multiplicidade, isto é, imanência e transcendência em "desequilíbrio perpétuo", porém, na tentativa harmônica perene e necessária.

A imanência cosmológica é a prática perspectiva no xamanismo amazônico, onde perpetua efetivamente um éthos ameríndio. Essa diferença de potencial transformativo dos seres, onde o ponto de vista de modus de existir de cada ente depende da tradução do xamã, até a inserção equivalente nas relações; ou seja, a operação de um profetismo de baixa intensidade do xamanismo (Idem, p. 181) em seu contínuo fusional. 


\section{SACRILEGENS

\section{A transformação}

A transformação xamânica é um processo gradual, profundo, com equalizações em todas as tangencias do ente. Muitos elementos entram nessa composição: a doença é concebida como alteração ou alienação alma (ELIADE, 1998, p. 224), quando ela promove a fuga do corpo (Idem, p. 244); no sonho se atinge a vida sagrada por excelência e se restabelecem relações diretas (ELIADE, 1998, p. 123) com entes sobrenaturais, almas dos antepassados, outros espíritos, dimensão onde se possibilita a recuperação do tempo mítico e as revelações da cosmogonia (Idem); o êxtase é a morte ritual, onde a condição material humana é superada (Ibidem, p. 115); nessas manifestações, o transe se torna o fundo virtual condutor da construção imaterial.

Embora todas as demandas do processo de produção de um xamã parecem estar diretamente ligadas a uma dimensão espiritual, é no corpo que vai se materializar toda imaterialidade. Tanto o xamanismo arcaico visto por Mircea Eliade, como o xamanismo ameríndio perspectivista de Viveiros de Castro, explicitarão a total necessidade da corporeidade.

O corpo sofrerá inferências marcantes sejam externas ou internas com o propósito de reconstrução dos órgãos como processos de manifestação mitológica (ELIADE, 1998, p. 50). Quando um xamã inicia o outro é considerado um "fazedor" de corpos. Este movimento é uma reprodução cíclica. Ciclo mítico de criação, assim como da fase da maturidade na capacidade de produzir vida (VIVEIROS DE CASTRO, 2014, p. 47), sempre pensado no sentido de restauração.

A metamorfose corporal é um elemento que transbordará a prática do xamã, para se tornar uma prática xamânica no socius ameríndio. "A fabricação subordina a natureza aos desígnios da cultura” (Idem). Nesse sentido, a circulação constante, natureza/cultura demarcada, reconhecida, replicada no molar, é uma continuação do entendimento xamânico da geografia mítica nos significados coletivos.

\section{A recriação}

A transformação é sempre a atividade de recriação da cosmogonia. O mito de origem, a história fundante, a recapitulação, rememorização e reatualização das narrativas de criação de cada povo (ELIADE, 1972, p. 21), distribuídos em várias 


\section{SACRILEGENS

manifestações da cultura. A atribuição ao um demiurgo na criação do ambiente, juntamente com elementos de composição do Universo, se desenvolve em concomitância a criação da humanidade.

A exposição da narrativa de reconstrução feita por Eliade é também localizada em várias expressões ameríndias como, por exemplo, do povo Bororo 4 , ou dos Krahô 5 , ou ainda, no registro meticuloso dos yanomami (KOPENAWA \& ALBERT, 2010). Logicamente, cada um com suas peculiaridades e diferenciações, pois na vasta existência indígena das Américas, a experiência dos povos se encontrará nos feixes mitológicos (LÉVI-STRAUSS, 2008) e nas práticas da cultura, porém possuem traços bem localizados.

A reconstrução da vida é tomada a cabo desde o mito fundante. Assim como o demiurgo, na narrativa, o fez para que existisse o primeiro ente, isso será revivido em ritual com longa duração até a conclusão de sua feitura. Na descrição detalhista de Viveiros de Castro (2014) o povo Yawalapíti do Alto Xingu, o demiurgo soprou fumaça de tabaco sobre toras de madeira em uma recamara de reclusão, criando primeiro a mulher, gerando os gêmeos Sol e a Lua (Idem, p.48). Essa rememorização será aplicada ao longo da vida do povo para que o processo não seja apenas uma narrativa, ou memorial, mas um registro permanente nos costumes, no corpo, no próprio sentido de existir.

Ao que tudo indica o complexo de construção da pessoa, na concepção xinguana, expresso na corporalidade, ultrapassa a dimensão do físico, efetuando o equilíbrio psicossocial, público e espiritual. No caso dos Yawalapíti, revivendo a narrativa da recamara de reclusão citada. A poderosa carga de significados está expressa nos três termos do sistema: "a fabricação do corpo, a exibição do corpo e a metamorfose", os domínios cosmológicos de constante comunicação tridimensional: natureza, cultura e sobrenatureza; como analisa Viveiros de Castro, dando a ideia de abrangência desse composto:

Se os Yawalapíti dizem que a reclusão é "para mudar o corpo", essa afirmativa não pode ser tomada como metáfora; ela deve ser tomada estritamente ao pé da letra. Desde que se entenda que o corpo, para os Yawalapíti, é algo diverso do que assim chamamos. Se a fabricação do corpo

4Lévi-Strauss: Saudades do Brasil - Documentário Completo. Canal TV Senado. 2019. Disponível em: $<$ https://www.youtube.com/watch?v=PK7HhohZzeE > Acesso em: 03 junho 2020.

5 A Visão do Xamã. Documentário a respeito dos xamãs do povo indígena Krahô, no Tocantins. Canal Tatiana Paranaguá. 2014. Disponível em: <https://www.youtube.com/watch?v=zvnaH-MlgKo > Acesso em 03 junho 2020. 


\section{SACRILEGENS

define o domínio da casa, da periferia da aldeia, do privado e do secreto, a exibição do corpo, seu uso como tela onde se depositam as marcas de estatuto (sexo, idade, papel cerimonial), caracteriza o pátio da aldeia, a vida pública, o confronto com as outras aldeias da região e o contexto cerimonial. (VIVEIROS DE CASTRO, 2014, p. 49).

Essa cultura xamânica do processo de transformação da distinção e identificação no corpo (VIVEIRO DE CASTRO, 2009, p. 49) é, portanto, uma transversalidade na diferença potencial do "desequilíbrio perpétuo" (Idem, p. 180), criando mecanismo de comunicação, diálogo e entendimento.

\section{O ritual}

O ponto de confronto perspectivo encontra correlações e a possibilidade de equivalência na atividade xamânica; estabelecer, em sua "busca de homologias" (CARNEIRO DA CUNHA, 2017, Apud VIVEIROS DE CASTRO, 2009, p. 172) uma frequência entre mundos respectivos é o fator intencional. Nesse sentido, o "ritual dos eventos místicos essenciais ocorridos desde a Criação" (ELIADE, 1998, p. 21), em suas expressões como a dança, canto, bebida, fumaça, funciona como elemento de conexão com a reatualização.

Nesse encontro de divergências perspectivas que constituem o cosmo, é que se potencializa o poder do xamã, e seus limites (VIVEIROS DE CASTRO, 2019, p. 173), substanciado, encarnado, relatado e relacionado. O ritual, então, se torna essa potência de manifestação de toda construção produzida através da interpretação das lâminas cosmológicas.

Um canto é repetido pelo peso do seu conteúdo, do que ele diz; quem o repassou; quem o trouxe de sua esfera de significado; essa importância potencial do que representa é o que impulsiona a dança (ELIADE, 1972, p. 17); “não basta conhecer o mito de origem, é preciso recitá-lo; em certo sentido, é uma proclamação e uma demonstração desse próprio conhecimento" (Idem); porém, o ritual, igualmente, o momento certo de ser dito, proclamado, recitado. Essa atmosfera, ou seja, o espírito das coisas, ou o sentido fundamental delas, precisa impregnar o ambiente onde os entes estão de maneira vívida.

A cosmologia ameríndia entendida, traduzida, pronunciada e experiênciada, vista no trabalho de Viveiros de Castro, encontrará ressonância no denso registro analisado por Mircea Eliade. Em ambos os casos: existir é um ritual de constante relação de significados. O plantio não é apenas pôr sementes na terra, regar e esperar 


\section{SACRILEGENS

crescer. Faz-se necessário conhecer toda a tradição mítica daquele grão, sua lenda, como veio a ser um alimento tão vigoroso e saudável, para que ao ser plantado, novamente ele se torne como na origem (ELIADE, 1972, p. 18); por isso, há quem conheça esse mito, e pode recitar cânticos para que todo percurso aconteça; assim, há uma relação de relembrar ao grão o comportamento esperado (Idem, p. 16), reiterando sua recriação exemplar. Essa ritualização da origem está em toda vida, como esse exemplo de Eliade do povo Osage, norte-americano:

\footnotetext{
Quando nasce uma criança Osage, convoca-se a presença de "um homem que falou com os deuses". Ao chegar à casa da parturiente, ele recita diante do recém-nascido a história da criação do Universo e dos animais terrestres. Somente depois disso é que o bebê é amamentado. Mais tarde, quando o bebê quer tomar água, chama-se novamente o mesmo homem ou um outro. Mais uma vez ele recita a Criação, completando-a com a história da origem da Água. Quando a criancinha atinge a idade de ingerir alimentos sólidos, volta o homem "que falou com os deuses" e recita novamente a Criação, mencionando também desta vez a origem dos cereais e de outros alimentos (ELIADE, 1972, p. 28).
}

Todo conjunto de elementos que compõem o xamanismo está intrinsecamente ligado ao processo ritual. Como vimos, eles tem seu aperfeiçoamento, manifestação, ensinamento e vivência através dos rituais. Segundo Eliade, é mais que uma replicação de narrativas ancestrais dos anciões, aos pais, e assim, aos filhos; trata-se obter a "função essencial do Tempo da origem que, é considerado um tempo "forte" justamente porque foi, de certo modo, o "receptáculo" de uma nova criação" (ELIADE, 1972, p. 29); tempo significativo, então, é o tempo ritualizado.

Como observado, o ritual é o elemento que proporciona a circulação da compreensão indígena como corpo integrante de um todo. É através do ritual que os processos de sentido, palavra, vão atuar como pensamento manifesto em toda sociedade indígena, influenciando assim, suas relações com todos os existentes e consigo mesmo.

\section{A cura}

A vivência dos povos de cultura xamânica é a tentativa perene de manifestar toda virtualidade potencial de sua existência. Na prática de atravessar o desequilíbrio perpetuo, talvez, algo que demonstre grande ambiguidade em sua expoência, seja a doença; que incitará um complexo, necessário, e precioso movimento de relação entre múltiplos envolvidos: a cura. 
A doença desempenhará um importante papel de muitas vias de condução. Nesse sentido, assim como qualquer outro elemento de importância, será necessário aprender a narrativa de sua origem (ELIADE, 1972, p. 22); e suas diferentes características: a doença como perturbação da mente em um sonho (Idem, p. 23); que também pode ser uma grande viagem onírica especialmente intensa (VIVEIROS DE CASTRO, 2014, p. 52); como mediadora de espíritos (Idem p.51); utilizada como substrato de aprendizado (ELIADE, 1972, p. 23); a doença como vingança de algum predação consumida (VIVEIROS DE CASTRO, 2009, p. 175); ela aparece também como ativadora de um grande esquema de mecanismo social, estabelecendo a integração da aldeia e o sistema político territorial (Idem, 2014, p. 52). Sua existência se torna fundamental para própria existência xamânica.

A doença como itinerário do ritual de cura amalgama, pelo menos, três atores principais, a saber: a crença do xamã em suas próprias técnicas; a crença do próprio enfermo ou da vítima dessas operações; e a confiança coletiva, que forma uma atmosfera (LÉVI-STRAUSS, 2008, p. 182) propícia para efetuação da cura. É preciso frisar que todos os elementos reunidos no contexto ritualístico não são mera encenação, mas de fato, o ponto culminante do processo de rememorar, reviver, efetivamente, em "toda sua vivacidade, originalidade e violência" (Idem, p. 196) a peleja contra os intricamentos da enfermidade. Novamente, como todo ciclo xamânico, conhecer a origem da doença, poder recitar seu mito é fundamental para o processo ritual de cura (ELIADE, 1972, p. 22) e sua eficácia.

A doença pode ser a despersonificação do ente. Um grande descolamento da sua personitude funcional do corpo (LÉVI-STRAUSS, 2008, p. 202); a perda do seu duplo, ou do espírito das partes que constituem o todo como força vital (Idem, p.203); uma extração violenta da densidade, conhecido como "roubo da alma"; isso registrado pelos três autores mobilizados aqui: Mircea Eliade (1998, p. 50) Viveiros de Castro (2014, p. 52) e Lévi-Strauss (2008, p. 202-203); o que implica, nos mesmos registros, a atividade do xamã na busca pela alma nos lugares sombrios e da posse de espíritos contrários que tenha efetuado o roubo, por encontro, desequilíbrio, sonho, tensão física, ou qualquer outra desfuncionalidade que altere o estado do enfermo.

A cura não é a simples atividades de se livrar da doença. É um grande processo de estabilização do corpo diante do atenuante desequilíbrio cosmológico; uma renovação dos órgãos, atualização espiritual e recolocação da alma (ELIADE, 1998, p. 50); um mecanismo de identificação do espírito causador (VIVEIROS DE CASTRO, 


\section{SACRILEGENS

2014, p. 51) e uma ação diplomática de finalização do estado alterando das várias dimensões (Idem, p. 52), até alcançar um fim de apaziguamento.

Consolidar uma taxativa plena sobre processo, efeito e resultado da cura não é a intenção nesse momento. Mircea Eliade trata preventivamente de alertar sobre sua abordagem como historiador das religiões ao tratar dessas e de outras atuações xamânicas; mas, deixa em aberto a possibilidade de contornos através da psicologia, sociologia e da etnologia (ELIADE, 1998, p. 08) para alcançarmos os mais diversos aspectos do tema. E embora, por causa da escolha do xamanismo ameríndio como melhor possibilidade de atualização da compreensão, o pós-estruturalismo deleuziano lançado mão por Viveiros de Castro (2009, p. 32) seja tomado em demasia, por conta de todas as possibilidades abertas; é no estruturalismo lévistraussiano (Idem, p. 233) que as estruturas de entendimento se estabelecerão (Ibidem, p. 247) de forma que alcance uma compreensão razoável.

A cura é, como objetivo principal, a harmonização de estado do ente; onde todos os conectivos espirituais e a cooperação entre os órgãos precisam funcionar como um grande organismo (LÉVI-STRAUUS, 2008, p. 204), atingindo o cadenciamento da "eficácia simbólica" (Idem, p. 205):

A cura consistiria, portanto, em tornar pensável uma situação dada inicialmente em termos afetivos, e aceitáveis, pelo espírito, dores que o corpo se recusa a tolerar. $\mathrm{O}$ fato de a mitologia do xama não corresponder a uma realidade objetiva não tem importância, pois que a paciente nela crê e é membro de uma sociedade que nela crê. Espíritos protetores e espíritos maléficos, monstros sobrenaturais e animais mágicos fazem parte de um sistema coerente que funda a concepção indígena do universo. A paciente os aceita ou, mais precisamente, jamais duvidou deles. O que ela não aceita são as dores incoerentes e arbitrarias que constituem um elemento estranho a seu sistema, mas que o xamã, recorrendo ao mito, irá inserir num sistema em que tudo se encaixa. (LÉVI-STRAUSS, 2008, p. 213).

O ritual da cura cria uma condição para que o enfermo possa atualizar o inconsciente através de um processo psicológico, manipulado através de toda construção mítica (Idem, p. 206-207); o cântico e as palavras proferidas tornam o paciente consciente do estado, seja alterado ou aquele que se pretende que o corpo retorne (Ibidem, p. 211) assim, todos os protagonistas retornam a ordem cosmológica desejada pelo processo. 


\section{SACRILEGENS

\section{Fundo espiritual}

Os elementos envolvidos no xamanismo ameríndio, visto acima, operam no fundo espiritual comum da América indígena, como foi dito no início, se desenvolvem com a aliança consensual a priori ou os arranjos a posteriori com os entes "não humanos”, inclui o existente indígena ao difuso patamar relacional possível. Mesmo que "o caminho não seja o mesmo nos dois sentidos" (VIVEIROS DE CASTRO, 2009. p. 208), e se tratando de povos da Amazônia, por exemplo, é essa compreensão com o encontro dos corpos que define "as condições intensivas do sistema" (Idem), e nesse sentido, o corpo indígena totalmente inserido no ambiente fractal.

Embora a aliança, arranjos, encontros, relações com diferentes existentes, seja uma constante em diversos povos indígenas, é a diferença de corpos que tornará a cultura xamânica tão necessária. Visto que o xamã é o que personifica a conexão entre corpos, consequentemente entre mundos, proporcionando a passagem nãodestrutiva do "fluxo semiótico entre humanos e não humanos" (VIVEIROS DE CASTRO, 2007, p. 19), eliminando o vácuo das partes comunicantes.

É por esse tipo de operação manifestada como cultura molar indígena, que "há, desde o início da colonização, uma ávida procura de uma "religião indígena" que se volta para o xamanismo (ou mais exatamente na pajelança) quando não encontra templos, ídolos ou sacerdotes mais semelhantes aos próprios” (POMPA, 2003; Apud SÁEZ, 2018), ou seja, a necessidade persistente de enquadrar a protagonização xamânica ao entendimento religioso ocidental. Mesmo sendo o pensamento xamânico, um assimilador de "espíritos", ou seja, o tráfego da "cultura” é contingente, dessa forma, o xamanismo segue capturando outras incursões, mesmo as colonizadoras, missionárias, ocidentais (Idem, p.16). O xamanismo não está alheio a nada, e dessa forma, não permanece extático.

Mas os patamares de habitação dos entes são difusos e convergentes. Desse modo, muitos outros existentes possuirão aptidão xamânica. Ou seja, não só humanos, mas, animais, não-humanos, espíritos, plantas, elementos (SÁEZ, 2018, p.19), em suma, a diversidade de corpos dos mais variados podem possuir propensão xamânica, e dessa forma, trafegar na canalização dos fluxos constantes, de contatos diversos. "Todos os nós da rede do xamã são xamãs" (Idem). Essa concepção de cultura que faz o xamanismo escapar do reducionismo religioso. 


\section{SACRILEGENS

O caminho arriscado de entendimento da cultura/espírito como fundo natural/comum dos existentes, por tanto contato/comunicação possível (constante), é desbravado no empreendimento levistraussiano das "Mitológicas", no "estudo das representações míticas da passagem da natureza à cultura”, nos aduzirá Viveiros de Castro (2007, p.34), a "um labirinto de caminhos tortuosos e equívocos, vias transversas, becos estreitos, impasses obscuros" (Idem), que nesse sentido, a tarefa mais perniciosa parece ser a necessidade da compreensão mística dos movimentos espirituais, por mera falta de recursos intelectivos da cognição que não alcança o modo de vida indígena.

Considerar, ou constatar, espírito/cultura como modo de vida molar de todo sócius ameríndio, nos obriga a cartografar o elemento operante desse recurso virtual, o xamanismo. E nesse percurso vasculhar cartografias profundas sobre o tema, como a de Lévi-Strauss $(1955 ; 1975 ;$ 2008), Óscar Calavia Sáez (2018) e as de Viveiros de Castro (2006; 2007; 2009; 2014); e ainda, por vias das Ciências das Religiões, Mircea Eliade (1972; 1998).

As variantes das possibilidades xamânicas são abertas rizomaticamente em todos os lados, como Sáez verifica em seu texto mobilizado aqui. Em Eliade vamos encontrar as camadas de atividades do corpo xamânico: como êxtase, viagem corporal; e o texto, a palavra, a sobrevivência das diferentes lâminas virtuais através dos mitos (ELIADE, 1972). Mas, Viveiros de Castro vai evocar o "plano de imanência" de Deleuze para situar seu conceito, intuição pré-conceitual e pressuposição do "fundo universal da realidade" como sendo o espírito (VIVEIROS DE CASTRO, 2007, p.33). E mesmo que verifiquemos como referência o vasto esmero dos autores supracitados, em descrever as atividades do xamanismo como sendo necessariamente espirituais, mobilizar a filosofia para uma ilustração de estado mais que lugar, talvez nos ajude a perceber sua instável permanência:

Os conceitos são como as vagas múltiplas que se erguem e que se abaixam, mas o plano de imanência é a vaga única que os enrola e os desenrola. $\mathrm{O}$ plano envolve movimentos infinitos que o percorrem e retornam, mas os conceitos são velocidades infinitas de movimentos finitos, que percorrem cada vez somente seus próprios componentes (DELEUZE \& GATTARI, 2011, p.51)

O espírito como presença a priori, como fundo,e como corpo, estabelece essa zona de instauração conceitual (Idem, p. 52), onde se instala o substrato da interpretação xamânica. E se o plano de imanência é "o fundo impensado do 


\section{SACRILEGENS

pensamento, que sustenta e condiciona o pensamento que se faz" (Ibidem, p.53); é nas zonas xamânicas - interespecífica, inter-humana ou intersocietária - que a espiritualidade vai se supersupor intensivamente em suas "adjacências horizontal ou de englobamento vertical" possibilitando a comunicação transversal (VIVEIROS DE CASTRO, 2009, p.171), ou a "perpetua disputa" de posição do emissor de afetos e agentividade.

O empreendimento de Viveiros de Castro, em sua obra, se embrenha em catalogar movimentos identificados como humanos pelas vias duplas perspectivistas, escavando as "representações míticas" que insiste numa cultura que represente a natureza. Porém, os registros mínimos das operações xamânicas, como o “cromatismo crepuscular céu-terra”(VIVIEIROS DE CASTRO, 2007, p.35), que concebe a capacidade de atingir universos invisíveis, seja da ordem do céus dos xapiri, que mostram as situações das florestas, de Davi Kopenawa(KOPENAWA \& ALBERT, 2010, p.327), ressonando os registros de trânsitos transcendentes feitos por Mircea Eliade (1998); ou as camadas de espíritos de todos das coisas existentes que encontram o ponto harmônico de existência entre si (ELIADE, 1972) (LÉVISTRAUUS, 2017), (VIVEIROS DE CASTRO, 2009), (SÁEZ, 2018), dão conta de uma condicionante espiritual por excelência.

Mas qual é a "distinção entre natureza e cultura" que é embaralhada pela tecnologia de psicoativos como o tabaco? (VIVEIROS DE CASTRO, 2007, p. 35); uma vez que já se sabe que várias plantas possuem a aptidão à atuação xamânica, por conseguinte, a relação de corpos seria uma preposição mais fecunda. Mas, é diante das relações exacerbadamente espirituais que o "fundo universalmente humano de todos os seres”, que insiste Viveiros de Castro, ganha ares mais incongruentes. Talvez, por algumas manifestações de afetos spinozistas (VIVEIROS DE CASTRO, 2009, p.56), possam ser consideradas mais humanas do que animal. E nesse sentido, certas atitudes clementes, façam um tigre ser denominado pai de uma indígena (DESCOLA, 2016), ou ainda, um rio ganhar status de avô de indígenas (KRENAK, 2019); porém, tudo parece estar contido na pré-concepção ocidental do que é uma atitude animal ou humana:

O modelo do espírito é o espírito humano, mas o modelo do corpo são os corpos animais; e, se a cultura é a forma genérica do eu e a natureza a do ele, a objetivação do sujeito para si mesmo exige a singularização dos corpos - o que naturaliza a cultura, isto é, a "incorpora" -, enquanto a subjetivação do objeto implica a comunicação dos espíritos - o que culturaliza a natureza, 


\section{SACRILEGENS

isto é, a sobrenaturaliza. A problemática ameríndia da distinção natureza/cultura, nesses termos, antes de ser dissolvida em nome de uma comum socialidade anímica humano-animal, deve ser relida à luz do perspectivismo somático. (VIVEIROS DE CASTRO, 2014, p.265).

Parece que o transcurso ocorre na capacidade de assimilação de espíritos. O xamã pode, assim como trafegar entre animais e outros entes, por exemplo, absorver elementos de espíritos ocidentais, como o cristianismo, e até mesmo se transformar em seu agente (SÁEZ, 2018, p.17). Diante de todo o preposto, essas possibilidades xamânicas podem produzir atmosferas variadas, como trocas de habitação; uma geografia virtual; e uma aglutinação de espíritos (Idem), uma vez que o xamanismo assimila grandes feixes de intenções, os sobrenaturalizando.

É possível que a grande pergunta perspectivista de Metafísicas Canibais: “a quem cabe a posição de humano aqui?” (VIVEIROS DE CASTRO, 2009, p.171) esteja no seu ponto de partida sobre o sistema teórico de Roy Wagner (2017) que decorre em "humanidade imanente" e "continuum sócio-espiritual dado desde sempre" (VIVEIROS DE CASTRO, 2009, p.38). Nesse sentido, parece que não há o elemento para perpetuar uma "humanidade", e sim, a imanência de uma espiritualidade que flui em diferentes entes, e afeta outros corpos e espíritos diferentes maneiras. Logo, a pergunta que talvez tenhamos que fazer seja: que espírito está ocupando o lugar aí? E não estamos falando de perspectiva:

\footnotetext{
Eu sou um humano, devo ver as coisas como um humano as vê, não como as vê uma onça. Os xamãs têm o poder de ver como as diferentes espécies veem, mas é necessário que voltem dessa viagem. Se veem as coisas como as onças as veem e ficam presos nessa visão, isso quer dizer que se tornaram onças e que não poderão voltar para contar a história: em resumo, trata-se de um xamã inútil e perigoso, um xamã "de mão única". Um xamã pode ver o mundo como uma onça, como um pecari e também, é claro, como um humano. (VIVEIROS DE CASTRO, 2007, p.100).
}

Tudo indica que no "perspectivismo ameríndio" há um lugar de humano reconhecido. Há, porém, outras diferenças entre estar, ser, e se tornar espírito. E não estamos falando de "possessão espiritual”, ideia percebida na cultura ocidental como controle do espírito que está dentro de um corpo (Idem). Se no perspectivismo ameríndio a possibilidade é ocupar o ponto de vista; os outros movimentos xamânicos realizados por indígenas, animais, plantas, espectros, seriam a habitação de um cosmo virtual necessário, que promoveria comunicações em determinados momentos, ultrapassando ascendência ou horizontalidades, ou misturando-as com 


\section{SACRILEGENS

uma ação "transversal” (VIVEIROS DE CASTRO, 2006,2007, 2009), "não definida por sua direção, mas pelos limites que infringe, e cuja máxima realização estaria numa 'comunicação entre incomunicáveis"” (SÁEZ, 2018, p. 17), contínua, intensa, conflitante, necessária, e virtual.

\section{Conclusão: sistema complexo}

A certeza que se estabelece quando o xamanismo, como conjunto de pensamento dos povos originários, é observado, é de que se trata de um complexo sistema. Mas não um sistema de crenças, como um olhar ocidentalizado poderia inferir sobre o modo de vida alheio ao seu. Pois pensar nas atribuições de significado de existência de diferentes povos como crença, é ignorar os aspectos "universais cognitivos da espécie humana" na transmissão socialmente determinada de certo modo de conhecimento (VIVEIROS DE CASTRO, 2009, p. 227) que nos leva acreditar no sistema em que estamos inseridos. E nesse sentido, nossas próprias ciências humanas já conseguem nos ajudar a não transformar a cultura alheia em "teologia dogmática”, “conjunto de proposições”, "um estado mental” (Idem, p. 228), mas, no caso do pensamento xamânico, o que tem sido dito repetidas vezes: uma relação de relações.

Os registros históricos do início do século XVI, dão conta que os invasores da pré-América não encontraram uma religião ameríndia propriamente dita; pois não sabiam o que era crê ou adorar, por isso não entendiam o evangelho de adorar um só Deus (Nóbrega 1556-57: II 320 Apud VIVEIROS DE CASTRO, 2014, p. 143); "não podiam ter religião e fé, que exigem a disposição em morrer por alguma coisa. Modo de crer, modo de ser” (Idem, p. 143 Apud Idem, p. 144). E ainda uma relação com outras perspectivas intrigantes "dispostos a tudo engolir, quando se os tinha por ganhos, eis que recalcitravam, voltando ao 'vômito' dos antigos costumes" (ANCHIETA 1555: II 194 Apud Ibidem, p. 129). Outro registro importante é do reformado calvinista Jean de Léry (1578): “a validação da cosmologia nativa pelo recurso à palavra dos pajés e profetas não significava o componente de "crença", no sentido políticoteológico do termo" (VIVEIROS DE CASTRO, 2014, p. 144) exatamente por faltar à sujeição, a entrega do juízo de vontade pela crença.

Se o compêndio xamânico com seus mitos, rituais, cânticos, narrativas, pinturas, significantes e significados, não é uma religião, de que estamos tratando? 


\section{SACRILEGENS

Provavelmente um grande labirinto será percorrido para se chegar à conclusão de que "o fundo universal da realidade é o espírito"; por isso a possibilidade infinita do "plano de imanência" que tanto apregoou Gilles Deleuze (VIVEIROS DE CASTRO, 2007, p. 33); porém, no caso de toda observação do modo de vida ameríndia, uma imanência de plano atualizado; uma imanência profunda, que retira o espírito do lugar transcendente e o absorve em convivência plena.

A vida ameríndia está transbordada de seus mitos de existência. Logo, não é a "experiência religiosa" que faz viver esses mitos, mas a presença constante destes em toda atmosfera molar. Ou seja, como já verificado, o espírito das coisas impregnando tudo, não como comemoração sagrada, mas como reiteração presente do sentido mítico (ELIADE, 1972, p. 18), e no caso, na ordinária vida quotidiana.

O xamanismo ultrapassa, então, a esfera ritualística, para se estender a um modo de vida intraespecífico; construindo uma epistemologia estético-política que produz sujeitos (VIVEIROS DE CASTRO, 2007, p. 43), modifica corpos, ordena a manifestação de diferentes afetos, e promove um fascinante fio condutor entre desequilíbrio perpétuo e a harmonia possível. E é justamente pela potência dessa construção, que o xamanismo não é reduzido a uma atividade mediadora de ritual, mas, a um entendimento das relações necessárias entres todos os envolvidos no ambiente de multinaturezas.

\section{Referências}

DELEUZE, Gilles. GUATTARI, Félix. O que é filosofia? Tradução: Bento Brado Jr e Alberto Alonso Muñoz. Coleção Trans. São Paulo. Editora 34. 2011.

DANOWSKI, Déborah. VIVEIROS DE CASTRO, Eduardo.Há mundo por vir? Ensaio sobre os medos e os fins. Desterro (Florianópolis). Cultura e Barbárie: Instituto Socioambiental.2015.

DESCOLA, Philippe. Outras naturezas, outras culturas. Tradução Cecília Ciscato. São Paulo. Editora 34. 2016.

ELIADE, Mircea. Mito e Realidade. São Paulo. Editora Perspectiva S. A. 1972.

ELIADE, Mircea. O Xamanismo e as técnicas arcaicas do êxtase. Trad. Beatriz PerroneMoisés e Ivone C. Benedetti.São Paulo. Martins Fontes. 1998.

KOPENAWA, Davi. AlBERT, Bruce. A queda do céu: Palavras de um xamã yanomami. Tradução Beatriz Perrone Moisés. São Paulo. Cia das Letras. 2010.

LÉVI-STRAUSS, Claude. Tristes trópicos. Tradução: Rosa Freire d'Aguiar. São Paulo. Companhia das Letras. 1955. 
LÉVIS-STRAUSS, Claude. A eficácia simbólica - Rio de Janeiro. Editor Tempo Brasileiro. 1975.

LÉVIS-STRAUSS, Claude. Antropologia Estrutural Dois - Tradução Beatriz Perrone-Moisés. São Paulo. COSAC NAIFY. 2008.

SÁEZ, Óscar Calavia. Xamanismo nas terras baixas: 1996-2016.BIB, n. 87, 3/2018 pp. 15-40.São Paulo. 2018.

VIVEIROS DE CASTRO, Eduardo. A floresta de cristal: notas sobre a ontologia dos espíritos amazônicos. Cadernos de campo, São Paulo, n. 14/15, p. 319-338, 2006.

VIVEIROS DE CASTRO, Eduardo. Encontros. Apresentação Renato Sztutman. Rio de Janeiro. Ed. Beco Azougue. 2007.

VIVEIROS DE CASTRO, Eduardo. Metafísicas canibais: Elemento para uma antropologia prós-estrutural. São Paulo. Ubu Editora, n-I edições, 2009.

VIVEIROS DE CASTRO, Eduardo. A inconstância da alma selvagem e outros ensaios de antropologia. São Paulo. Editora Cosac Naify, 2014.

WANGER, Roy. A invenção da cultura. São Paulo. Ubu Editora. Coleção: Argonautas. 2017. 